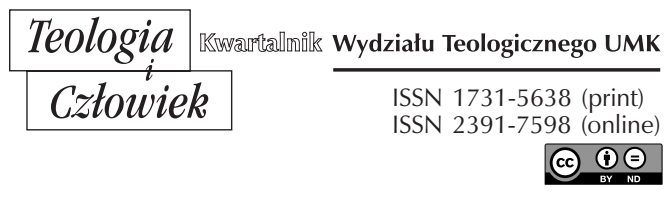

52(2020)4, ss. $73-86$

KS. SŁAWOMIR JEZIORSKI

WYŻSZE SEMINARIUM DUCHOWNE W RZESZOWIE UNIWERSYTET PAPIESKI JANA PAWŁA II W KRAKOWIE

\title{
LEX ORANDI JAKO INSPIRACJA DLA SYNODALNEGO MODUS VIVENDI KOŚCIOŁA
}

DOI: http://dx.doi.org/10.12775/TiCz.2020.051

Streszczenie. Synodalność Kościoła znajduje swój szczególny wyraz w celebracji eucharystycznej. Odnowione księgi liturgiczne przewidują specjalny formularz za synod lub sobór, którego treść wyraża właściwe takim zgromadzeniom linie teologiczne. Niniejszy artykuł jest próbą odczytania treści teologicznych dwóch kolekt wspomnianego wyżej formularza. Po wstępie uzasadniającym podjęcie takiego tematu, zostanie przeprowadzona analiza tekstów liturgicznych. Na tej podstawie zostaną wyszczególnione pewne elementy teologiczne, które, jako wspólne dla obu oracji, mogą być liniami przewodnimi dla modus vivendi Kościoła synodalnego. Owocem takiej syntezy jest wizja Kościoła, który pielgrzymuje ku Ojcu, napełniany Duchem Świętym rozeznaje to, co Bogu jest miłe, a podążając za tym, wzrasta w poznaniu prawdy i własnej świętości.

Słowa kluczowe: Kościół; Eucharystia; synod; synodalność.

Abstract. Lex Orandi as an Inspiration for the Synodal Modus Vivendi of the Church. Synodality of the Church finds its particular expression in the Eucharistic celebration. Renewed liturgical books provide special prayers for synods or councils, the content of which expresses theological direction typical of that kind of ecclesial congregation. This paper is an attempt to analyse two orations of the mentioned celebration. After an introduction justifying the choice of the topic, an analysis of liturgical texts is 
presented. Next, the author focuses on some theological features which are common to the both prayers and might be considered as guidelines for modus vivendi of the Church. The result of that synthesis is an image of the Pilgrim Church on a journey to the Father, and filled with the Holy Spirit. The Pilgrim Church discerns what is pleasing to God and thus grows in knowledge of the truth and in holiness.

Key word: Church; Eucharist; synodality; synod.

\section{WPROWADZENIE}

Pojęcie synodalności ${ }^{1}$ coraz częściej staje się we współczesnej eklezjologii kluczem do zrozumienia natury i misji Kościoła. Jak zaznaczył papież Franciszek, w swoim przemówieniu podczas uroczystości upamiętniającej 50. rocznicę ustanowienia Synodu Biskupów, „droga synodalności jest tą drogą, której Bóg oczekuje od Kościoła trzeciego tysiąclecia”2. Wskazany kierunek myślenia o Kościele znalazł odzwierciedlenie w pracach Międzynarodowej Komisji Teologicznej, która w 2018 roku wydała dokument zatytułowany „Synodalność w życiu i misji Kościoła”, w całości dedykowany temu zagadnieniu. We wskazanym tekście Komisja zaznacza, że oczekiwana przez Boga synodalna droga Kościoła jest kształtowana i karmiona Eucharystią . Dokument w ten sposób podejmuje myśl zawartą w Caeremoniale Episcoporum, który podkreśla, że synodalna natura Kościoła objawia się w sposób najpełniejszy w świętej liturgii ${ }^{5}$. W tym

${ }^{1}$ Celem niniejszego opracowania nie jest analiza samego pojęcia synodu oraz wynikającej z niego synodalności. O samej etymologii, znaczeniu i teologii „synodu”, por. G. Lampe, A Patristic Greek Lexicon, Oxford 1968, s. 1334-1335; S. Dianich, „Sinodalità”, w: Teologia, red. G. Barbaglio, G. Bof, S. Dianich, Cinisello Balsamo 2002, s. 1522-1531; P. Zurek, Indagine sulla sinodalità: la riflessione cattolica dopo il Concilio Vaticano II con alcuni risvolti ecumenici, Roma 2002.

2 Franciszek, „Synodalnośc” konstytutywnym wymiarem Kościoła, „L'Osservatore Romano". Wydanie polskie 11 (377) 2015, 5 (AAS 107 (2015), 1139).

3 Commissione Teologica Internazionale, La sinodalità nella vita e nella missione della Chiesa, Città del Vaticano 2018.

${ }^{4}$ Commissione Teologica Internazionale, La sinodalità nella vita e nella missione della Chiesa, 47.

${ }^{5}$ Por. Caeremoniale Episcoporum, ex Decreto Sacrosancti Oecumenici Concilii Vaticani II instauratum, auctoritate Ioannis Pauli PP. II promulgatum, Editio Typica, Città del Vaticano 1995, 1169. 
świetle zasadne wydaje się zwrócenie uwagi na celebrację eucharystyczną, aby w lex orandi Kościoła odnaleźć intuicje, które, będąc treścią modlitwy, mogą stawać się elementem kształtującym owo synodalne modus vivendi Ecclesiae synodalis.

O ile cała eucharystia, jako sakrament jedności i więź miłości ${ }^{6}$, jest epifanią Kościoła w drodze, o tyle wśród teksów euchologijnych znaleźć można te, które w sposób szczególny przeznaczone są na celebracje związane ze zgromadzeniem synodalnym. Jako takie, wyrażają one właściwą takim wydarzeniom myśl teologiczną. Wśród nich znajduje się formularz mszalny Pro concilio vel synodo ${ }^{7}$, który zawiera dwie kolekty, modlitwę nad darami, modlitwę po komunii oraz stosowne antyfony. Formularz ten jest owocem posoborowej reformy liturgicznej i jako taki wpisuje się w odnowioną świadomość synodalną Kościoła.

W niniejszym opracowaniu ograniczymy się do przedstawienia głównych linii teologicznych kolekt, które wyrażają charakter całej celebracji ${ }^{8}$. Po ich prezentacji zostaną wskazane główne myśli, które są wspólne dla obydwóch modlitw i to one będą treścią syntetazy niniejszego opracowania.

\section{KOLEKTA ECCLESIAE TUAE}

Pierwsza z kolekt, która została umieszczona w mszale Pawła VI $\mathrm{w}$ formularzu przeznaczonym na modlitwę za zgromadzenie synodalne, prezentuje się w następujący sposób:

Ecclesiae tuae, Domine, rector et custos, infunde, quaesumus, famulis tuis spiritum intellegentiae, veritatis et pacis, ut, quae tibi placita sunt, toto corde cognoscant et, agnita, tota virtute sectentur' ${ }^{9}$.

${ }^{6}$ Por. Augustyn, Homilia 26,13, w: Homilie na Ewangelię i pierwszy list św. Jana, cz. 1, Warszawa 1977, s. 376.

7 Por. $\mathrm{MR}^{2008} 1086\left(\mathrm{MR}^{2008}\right.$ - Missale Romanum ex decreto Sacrosancti Oecumenici Concilii Vaticani II instauratum auctoritate Pauli PP. VI promulgatum, Ioannis Pauli PP. II cura recognitum, Editio typica tertia, LEV, Città del Vaticano 2008).

8 Por. Ogólne Wprowadzenie do Mszału Rzymskiego, Poznań 2006, s. 54.

${ }_{9} \mathrm{MR}^{2008} 1086$.

Polskie oficjalne tłumaczenie niniejszej modlitwy brzmi: 
Modlitwa ta nie jest nową formułą. Jej korzenie sięgają starożytnych ksiąg liturgicznych. W Sakramentarzu gregoriańskim ${ }^{10} \mathrm{z}$ VII wieku odnaleźć możemy następujący tekst:

Da populo tuo quaesumus domine spiritum veritatis et pacis, ut et te tota mente cognoscat, et quae tibi sunt placita toto corde sectetur ${ }^{11}$.

Przedstawiona modlitwa znajduje się w sekcji Orationes cottidianas. Taka kolokacja wskazuje jej przeznaczenie, jakim była codzienna modlitwa ludu Bożego. W tak wyrażonej oracji sam lud Boży jest podmiotem i zarazem beneficjentem daru, o który prosi, a którym jest Duch Święty: Da populo tuo Spiritum veritatis et pacis. Co ważne, ostateczny cel modlitwy nie jest skoncentrowany na samym ludzie. Dar Ducha Świętego, upragniony przez modlących się, widziany jest jako ten, który ma otworzyć proszących na podwójny cel: poznanie Boga i podążanie za tym, co się Jemu podoba. Poznanie to dokonuje się całym umysłem tota mente, a podążanie za tym co się Bogu podoba odbywa się całym sercem, toto corde. Modlitwa ta wskazuje pragnienie osobowej więzi z Bogiem, która jest nadrzędna wobec podążania za tym, co się Bogu podoba. Zarówno w poznaniu, jak i w wypełnianiu woli Boga pojawia się przymiotnik totus, który wyraża całkowite zaangażowanie $\mathrm{w}$ relację $\mathrm{z}$ Panem.

W nieco późniejszym Sakramentarzu z Fuldy ${ }^{12}$ z X wieku spotykamy zmodyfikowaną formułę modlitewną, która brzmi następująco:

„Boże, Ty jesteś Rządcą i Opiekunem swojego Kościoła,

daj Twoim sługom zgromadzonym na Synodzie (Soborze) ducha rozumu, prawdy i pokoju,

aby gorliwie starali się poznać Twoją wolę i z całą mocą ją wypełniali” (MRDP 122).

10 Sakramentarz gregoriański to księga liturgiczna zawierająca teksty modlitw liturgicznych, przeznaczona do celebracji papieskich, datowana na VII wiek. Por. C. Vogel, Medieval Liturgy: An Introduction to the Sources, Washington 1986, s. 79-102.

${ }^{11} \mathrm{GrH} 921$ ( $\mathrm{GrH}$ - Le sacramentaire Grégorien. Ses principales formes d’après les plus anciens manuscrits, ed. J. Deshusses, vol. 1, Éd. Universitaires Fribourg Suisse, Fribourg Suisse 1979).

${ }^{12}$ Sakramentarz z Fuldy należy do rodziny ksiąg liturgicznych mieszanych z X wieku. Ta grupa manuskryptów nie ma bezpośredniego związku z późniejszym Mszałem Rzymskim Piusa V. Por. C. Vogel, Medieval Liturgy: An Introduction to the Sources, Washington 1986, s. 102-105. 
infunde quaesumus famulis tuis domine deus spiritum veritatis et pacis, ut, quae tibi placita sunt, toto corde cognoscant et, agnita, tota virtute sectentur ${ }^{13}$

To, co istotne, modlitwa, pomimo swojego podobieństwa, znalazła się w nowym kontekście celebracyjnym. W dziesięciowiecznym Sakramentarzu służy ona jako kolekta w formularzu mszy wotywnej Ad postulandam Spiritus Sancti gratiam. Modlitwa codzienna została więc zaadoptowana do konkretnej celebracji, której treść odnosi się do Ducha Świętego. Porównanie obu tekstów wskazuje też pewne różnice:

\begin{tabular}{|l|l|}
\hline \multicolumn{1}{|c|}{ GrH } & \multicolumn{1}{c|}{ Fulda } \\
\hline $\begin{array}{l}\text { Da populo tuo quaesumus domine } \\
\text { spiritum veritatis et pacis, }\end{array}$ & $\begin{array}{l}\text { Infunde quaesumus famulis tuis domine } \\
\text { deus spiritum veritatis et pacis, }\end{array}$ \\
sunt placita toto corde sectetur & $\begin{array}{l}\text { ut, quae tibi placita sunt, toto corde } \\
\text { cognoscant et, agnita, tota virtute sectentur }\end{array}$ \\
\hline
\end{tabular}

W pierwszej części modlitwy, główne zmiany dotyczą czasownika oraz podmiotu modlitwy. Prosta forma da została zastąpiona czasownikiem infundo, który wskazuje na sposób przychodzenia Ducha: jest On nie tylko dany, ale wlany wewnątrz, penetruje wnętrze tych, którzy o Niego proszą ${ }^{14}$. Druga modyfikacja dotyczy tych, którzy są adresatami daru. Tekst z X wieku określa ich mianem famuli. Taki zwrot, często spotykany w chrześcijaństwie, możemy uznać za bliskoznaczny dla określenia populus, choć zaznaczyć trzeba w tym przypadku akcent położony jest na postawę pokory wobec Boga, jako dawcy Daru ${ }^{15}$.

Porównanie drugiej części formuły modlitewnej ujawnia głębsze modyfikacje. Przede wszystkim dar Ducha Świętego nie służy już samemu poznaniu Boga, ale temu, co się jemu podoba. Czasownik cognosco został skojarzony z quae Deo placita sunt. To właśnie rzeczy, które podobają się

${ }^{13}$ Fulda 1795 (Fulda - Sacramentarium Fuldense saeculi X. Cod. Theol. 231 der K. Universitätsbibliothek zu Göttingen. Text und Bilderkreis (43 Tafeln). Als Festgabe des Historischen Vereins der Diözese Fulda zum 50 Jährigen Priesterjubiläum Sr. Eminenz des Hochwürdigsten Herrn Fürstbischofs von Breslau, Georg Kardinal Kopp, ehemaligen Bischofs von Fulda (1881-1887), ed. G. Richter, A. Schönfelder, Fulda 1912, (HBS 101), Henry Bradshaw Society, London 1977).

${ }^{14}$ Słownik łacińsko-polski, red. M. Plezia, t. III: I-O, Warszawa 1998, s. 155.

15 Por. M.P. Ellebracht, Remarks on the vocabulary of the ancient orations in the Missale Romanum, Utrecht 1963, 30. 
Bogu są teraz przedmiotem poznania w Duch Świętym, a jako poznane stają się przedmiotem, za którym chrześcijanie mają podążać. Poprzez taką modyfikację akcent $\mathrm{z}$ osobowej relacji Boga $\mathrm{z}$ Jego ludem, został przeniesiony na poznanie i pełnienie woli Bożej. Narzędziem poznania w tym przypadku nie jest już umysł, ale serce, co zgodne jest z przekonaniem, że poznanie Boga nie jest jedynie aktem intelektualnym, ale działaniem angażującym całego człowieka ${ }^{16}$. Podążanie za tym, co poznane, dokonuje się z kolei tota virtute, całą mocą. Konieczne wydaje się jednak przypomnieć, że jest to moc tych, którzy są napełnieni Duchem Świętym ${ }^{17}$. Kontekst całej modlitwy wyklucza pelagiańskie zabarwienie tekstu, które zakładałoby, że człowiek może własną mocą osiągnąć zbawienie.

Ten krótki szkic historyczno-krytyczny pozwana nam spojrzeć teraz na modlitwę, która została zaadaptowana w mszale Pawła VI do celebracji eucharystii synodalnej. Przytoczony wyżej tekst zestawmy z modlitwą z Sakramentarza z Fuldy. Rezultat takiego porównania wygląda w następujący sposób:

\begin{tabular}{|l|l|}
\hline \multicolumn{1}{|c|}{ Fulda } & \multicolumn{1}{|c|}{ MR 2008 } \\
\hline $\begin{array}{l}\text { infunde quaesumus famulis tuis domine } \\
\text { deus spiritum veritatis et pacis, ut, quae } \\
\text { tibi placita sunt, toto corde cognoscant et, } \\
\text { agnita, tota virtute sectentur }\end{array}$ & $\begin{array}{l}\text { Ecclesiae tuae, Domine, rector et custos, } \\
\text { infunde, quaesumus, famulis tuis spiritum } \\
\text { intellegentiae, veritatis et pacis, ut, quae } \\
\text { tibi placita sunt, toto corde cognoscant et, } \\
\text { agnita, tota virtute sectentur }\end{array}$ \\
\hline
\end{tabular}

Pierwszym elementem, który wyróżnia nową formułę modlitewną, są początkowe słowa inwokacji skierowanej do Boga. Tradycyjny zwrot Domine Deus został zastąpiony bardziej rozbudowanym zwrotem, w którym Bóg ukazany jest jako rector i custos swojego Kościoła. O ile w Mszale określenie Boga jako rector występuje także w innych modlitwach $^{18}$, o tyle słowo custos, obecne w tej modlitwie, jest jedynym takim określeniem w całej księdze liturgicznej. Całość inwokacji wskazuje na osobistą relację Boga z Jego Kościołem. To On jest jego rządcą i stróżem.

${ }^{16}$ Por. Y. Congar, Les voies de Dieu vivant. Théologie et vie spirituelle, Paris 1962, s. 83.

17 Por. Mk 12,30; Dz 1,8.

${ }_{18} \mathrm{MR}^{2008}$ 474, MR ${ }^{2008} 874, \mathrm{MR}^{2008}$ 1058, $\mathrm{MR}^{2008}$ 1081, MR $\mathrm{MR}^{2008}$ 1083, MR ${ }^{2008} 1086$. 
Wzywany w ten sposób, proszony jest o dar Ducha Świętego dla swoich sług. W porównaniu $\mathrm{z}$ modlitwą $\mathrm{z} \mathrm{X}$ wieku, w aktualnej modlitwie pojawia się także intellegentia, która obok veritas i pax staje się przymiotem upragnionego Ducha. Bez zmian natomiast pozostaje cel, dla którego słudzy Boga są napełniani Duchem: jest nim poznanie tego, co podoba się Bogu i podążanie za tym.

Podsumowując treść pierwszej z analizowanych modlitw, możemy wyróżnić kilka elementów teologicznych. Tym, który jest źródłem życia Kościoła, który nim kieruje i go strzeże, jest sam Bóg. To On posyła także Kościołowi Ducha Świętego, który pozwala wiernym poznawać, co jest miłe Bogu i pozwala za tym podążać. Ośrodkiem poznawania właściwej drogi jest serce ${ }^{19}$, które wyraża holistyczne zaangażowanie człowieka z całym jego wewnętrznym światem uczyć, pragnień i decyzji. Natomiast Duch, którym jest ono napełniane jest Duchem zrozumienia, prawdy i pokoju.

\section{KOLEKTA DEUS, QUI POPULIS TUI}

Druga z kolekt proponowanych przez mszał rzymski w formularzu Pro concilio vel synodo przestawia się w następujący sposób:

Deus, qui populis tuis indulgentia consulis et amore dominaris, da spiritum sapientiae quibus dedisti regimen disciplinae, ut plebs tua ad veritatis agnitionem pleniorem et sanctitatis tibi acceptum ducatur augmentum ${ }^{20}$.

Także w tym przypadku mamy do czynienia z modlitwą, która posiada wielowiekową historię. Jej źródło odnajdujemy w Sakramentarzu

19 Por. J. de Fraine, A. Vanhoye, „Serce”, w: Słownik teologii biblijnej, red. X. Léon-Dufour, Poznań 1994, s. 871-874

${ }^{20}$ MR 1086-C2. Oficjalne polskie tłumaczenie tekstu brzmi:

„Boże, Ty się opiekujesz swoim ludem i z miłością nim kierujesz, udziel ducha mądrości powołanym do rządzenia Kościołem, aby prowadzili Twój lud do pełniejszego poznania prawdy i wzrostu w świętości” (MRDP 122). 
gregoriańskim, w którym pełni ona funkcję drugiej kolekty formularza Orationes in natale papae, a jej forma przedstawia się następująco:

Deus qui populis tuis indulgentiam consulis et amore dominaris, da spiritum sapientiae quibus dedisti regimen disciplinae ut de profectu sanctarum ovium fiant gaudia aeterna pastorum ${ }^{21}$

Antyczna modlitwa, przeznaczona była na dzień konsekracji biskupiej, co determinuje sposób jej odczytania: jest to modlitwa wstawiennicza, którą Kościół kieruje do Boga, prosząc o dary dla tych, którzy są wybrani do pełnienia urzędu biskupiego. Adresatem modlitwy jest Bóg widziany jako udzielający ludowi czułości i rządzący z miłością swoim Kościołem. W takim kontekście rozlega się prośba o Ducha mądrości dla tych, którym został udzielony urząd nauczania. Beneficjentem epikletycznej modlitwy Kościoła są pasterze ludu Bożego. W swojej drugiej części modlitwa wskazuje motyw takiej prośby. Duch mądrości ma pomóc w rozwoju owczarni, a taki owoc z kolei staje się źródłem wiecznej radości pasterzy.

Modlitwa z Sakramentarza gregoriańskiego została zaadaptowana w Mszale Piusa V. W tej księdze liturgicznej zmienił się jednak jej kontekst. Odnaleźć ją możemy w formularzu na wspomnienie świętych papieży: Missae pro aliquibus locis. Die 3 Iulii. In Commemoratione Omnium Ss. Summorum Pontificum. W takim położeniu modlitwa przybrała nieco zmodyfikowaną formę:

Deus, qui populis tuis indulgentia consulis, et amore dominaris: da spiritum sapientiae, suffragantibus meritis Antistitum Ecclesiae tuae, quibus dedisti regimen disciplinae; ut de profectu sanctarum ovium fiant gaudia aeterna pastorum ${ }^{22}$

Zestawienie obu modlitw pomoże nam lepiej uchwycić zmiany, które wprowadził redaktor:

${ }^{21} \mathrm{GrH} 824$.

${ }^{22} \mathrm{MR}^{1962}$, 990 (MR ${ }^{1962}$ - Missale Romanum ex decreto SS. Concilii Tridentini restitutum Summorum Pontificium cura recognitum, Editio typica 1962, ed. M. Sodi, A. Toniolo, Città del Vaticano 2007). 


\begin{tabular}{|l|l|}
\hline \multicolumn{1}{|c|}{ GrH 824 } & \multicolumn{1}{c|}{ MR1962 } \\
\hline $\begin{array}{l}\text { Deus qui populis tuis indulgentiam consulis } \\
\text { et amore dominaris, da spiritum sapientiae } \\
\text { quibus dedisti regimen disciplinae ut de } \\
\text { profectu sanctarum ovium fiant gaudia } \\
\text { aeterna pastorum }\end{array}$ & $\begin{array}{l}\text { Deus, qui populis tuis indulgentia consulis, } \\
\text { et amore dominaris: da spiritum sapientiae, } \\
\text { suffragantibus meritis Antistitum } \\
\text { Ecclesiae tuae, quibus dedisti regimen } \\
\text { disciplinae; ut de profectu sanctarum ovium } \\
\text { fiant gaudia aeterna pastorum }\end{array}$ \\
\hline
\end{tabular}

Główny element, który znajdujemy w modlitwie z Mszału Piusa $\mathrm{V}$, to wtrącenie w formie ablativus absolutus dotyczące wstawiennictwa wspominanych świętych papieży, których zasługi mają przyczynić się do prośby, którą już wcześniej omówiliśmy. Taka zmiana z jednej strony jest próbą dostosowania modlitwy do nowego kontekstu, z drugiej jednak odzwierciedla także ducha epoki, w której wstawiennictwo świętych miało duże znaczenie w życiu Kościoła ${ }^{23}$. Ponadto w tekście pojawia się jedna korekta ortograficzna, która zmienia nieco strukturę rozwinięcia inwokacji. Accusativus indulgentiam, poprzez usunięcie głoski $m$ przybrał funkcję ablativus i wyraża już nie tyle dar łaskawości, co sposób działania Boga. W nowej strukturze także sam czasownik zmienił swój charakter, przybierając formę nieprzechodnią. W wyniku takiego zabiegu edytorskiego nie chodzi o udzielanie ludowi czułości, ale o troskę z czułością nad ludem i pocieszanie go $^{24}$.

Reforma liturgiczna przyniosła kolejną modyfikację w modlitwie ${ }^{25}$, która została podyktowana jej nowym kontekstem celebracyjnym. Zestawienie modlitwy przedsoborowej z obecnie używaną pozwoli nam uchwycić różnice:

${ }^{23}$ Por. E. Cattaneo, Il culto cristiano in Occidente. Note storiche, Roma 1983, $270-272$.

${ }^{24}$ Por. Słownik łacińsko-polski, red. M. Plezia, t. I: A-C, Warszawa 1998, s. $723-724$.

${ }^{25}$ Warto $\mathrm{w}$ tym momencie dodać, że modlitwa w takiej formie, w jakiej znajduje się w Mszale Piusa V, weszła także do Mszału Pawła VI jako tekst własny na wspomnienie papieża Grzegorza Wielkiego (3 września), otrzymując jedynie modyfikację, która nie wskazuje już na zasługi wszystkich papieży, ale na wstawiennictwo Grzegorza Wielkiego:

„Deus, qui populis tuis indulgentia consulis et amore dominaris,

da spiritum sapientiae, intercedente beato Gregorio papa,

quibus dedisti regimen disciplinae,

ut de profectu sanctarum ovium fiant gaudia aeterna pastorum" (MR $\left.{ }^{2008} 822\right)$. 


\begin{tabular}{|l|l|}
\hline \multicolumn{1}{|c|}{ MR1962 } & \multicolumn{1}{c|}{ MR 2008 } \\
\hline $\begin{array}{l}\text { Deus, qui populis tuis indulgentia consulis, } \\
\text { et amore dominaris: da spiritum sapientiae, } \\
\text { stfffragantibus meritis Antistitum Eectesiae- } \\
\text { tuae, quibus dedisti regimen disciplinae; } \\
\text { ut de profectu sanctarum ovium fiant } \\
\text { gaudia aeterna pastorum }\end{array}$ & $\begin{array}{l}\text { Deus, qui populis tuis indulgentia consulis } \\
\text { et amore dominaris, da spiritum sapientiae } \\
\text { quibus dedisti regimen disciplinae, }\end{array}$ \\
$\begin{array}{l}\text { ut plebs tua ad veritatis agnitionem } \\
\text { pleniorem et sanctitatis tibi acceptum } \\
\text { ducatur augmentum }\end{array}$ \\
\hline
\end{tabular}

Powyższe zestawienie nakazuje skierować uwagę na drugą część modlitwy, która uległa modyfikacji. Najbardziej znacząca zmiana dotyczy ostatecznego celu modlitwy. Jej beneficjentem nie są już pasterze Kościoła i ich wieczna radość, ale sam lud Boży, który przez pasterzy jest prowadzony. Takie zadanie biskupów wyraża bierna forma czasownika duco. Modlitwa wyraża podwójny cel, który jest horyzontem ludu pielgrzymującego pod przewodem napełnionych duchem mądrości pasterzy. Pierwszy z nich to pełniejsze poznanie prawdy. Użyty w tym przypadku stopień wyższy przymiotnika plenus (comparativus - plenior) wskazuje na dynamiczny wymiar poznawania, w którym nie chodzi o akt pełnego poznania, ale o nieustanne, pełniejsze poznawanie prawdy. Drugi cel modlitwy to wzrost świętości ludu Bożego, który byłby przyjęty przez samego Boga. Zarówno pierwsza, jak i druga intencja modlitwy wskazuje więc na wspólnotę ludu Bożego, którego pielgrzymowanie ma wydać konkretne owoce. W tym kontekście zmiana formuły odzwierciedla pewną wizję eklezjologii, w której cały Lud Boży jest przedmiotem troski Boga, pasterz natomiast we wspólnocie Kościoła pełni rolę służebną ${ }^{26}$.

\section{W KIERUNKU SYNTEZY TEOLOGICZNEJ}

Zestawiając treści obydwóch modlitw, przeznaczonych na celebrację Eucharystii za zgromadzenie synodalne, spróbujmy wskazać kilka elementów wspólnych, które mogą być liniami przewodnimi w kształtowaniu mentalności synodalnej Kościoła.

${ }^{26}$ Por. Konstytucja Dogmatyczna o Kościele 18, w: Sobór Watykański II, Konstytucje, dekrety, deklaracje. Tekst łacińsko-polski, Poznań 2008, s. 175. 
Obydwie modlitwy rozpoczynają się od inwokacji skierowanej do Boga Ojca. W jednej z nich jest on wprost nazwany rector oraz custos, druga natomiast wskazuje Jego rolę pośrednio poprzez zaangażowanie, które objawia wobec Kościoła. On troszczy się o niego z czułością oraz kieruje nim z miłością. Taki sposób odniesienia do Boga, w którym chrześcijanie uznają Go za pierwszego stróża Kościoła, wskazuje, że synodalność jest drogą inspirowaną przez Boga Ojca ${ }^{27}$. Kościół, który pragnie prawdziwie żyć secundum modum vivendi synodalis, nie może zwrócić się ku sobie samemu, ale musi swój wzrok i serce zwrócić ku Temu, który jest u początku, który jest stróżem i rządcą Kościoła, i którego Kościół jest własnością ${ }^{28}$.

Inwokacja skierowana do Ojca przeradza się w modlitwę o dar Ducha Świętego. To drugi element, który naznacza obydwie modlitwy. Duch Święty jest tutaj widziany jako dar Ojca, który posłany objawia się w konkretnych przymiotach. Modlitwy mówią o zdolności poznawania, prawdzie, pokoju i mądrości.

Beneficjentami daru Ducha Świętego jest cała wspólnota Kościoła. O ile modlitwy mówią o całym ludzie Bożym, o tyle wyróżniona w prośbach jest także rola pasterzy. Są oni tymi, którzy nie stoją ponad ludem, ale otrzymali szczególną odpowiedzialność troski o Kościół. Obecność Ducha Świętego, która jest przedmiotem modlitwy Kościoła, nie jest jednak celem samym w sobie. Duch, będąc „zasadą synodalności”29, jest dany, aby wprowadzić w Kościół konkretną dynamikę wędrowania, innymi słowy, aby uczynić Kościół ludem w drodze.

Pierwsza z modlitw wskazuje na kryterium, któremu poddane jest pielgrzymowanie Kościoła. To podążanie za tym, co jest rozpoznane jako podobające się Bogu, a więc zgodne z Jego wolą. W ten sposób po raz kolejny modlitwa objawia że synodalność jest drogą inspirowaną przez Boga ale także ukierunkowaną ku Niemu, ku poznaniu Jego woli i po-

${ }^{27}$ Por. Franciszek, „Synodalność” konstytutywnym wymiarem Kościoła, s. 5.

${ }^{28}$ Dokument „Sinodalità nella vita e nella missione della Chiesa”, mówiąc o Kościele, wskazuje, że jako Lud Boży „ jest wezwany i uzdolniony do tego, aby zwrócić swoje pielgrzymowanie w misji ku Ojcu, przez Syna, w Duchu Świętym” (nr 43, tłumaczenie własne).

${ }^{29}$ Commissione Teologica Internazionale, La sinodalità nella vita e nella missione della Chiesa, 46. 
dążaniu za nią. W tym kontekście droga synodalna ukazuje konieczność rozeznawania, o której wielokrotnie wspomina obecny papież $\dot{z}^{30}$.

Druga z modlitw dodaje dwie charakterystyki, które, choć są przedstawione jako cel, mogą być widziane także jako owoc podążania opartego na zasadzie rozpoznawania woli Boga. Pierwsza z nich to coraz pełniejsze poznawanie prawdy. Takie poznawanie jest dynamicznym procesem, który może dokonywać się tylko w drodze, mocą Ducha Świętego. Drugi owoc synodalnej drogi Kościoła to wzrost świętości objawiający się w życiu ludu Bożego. Ten owoc, który wyraża „najpiękniejsze oblicze Kościoła” ${ }^{31}$ nie jest efektem ludzkiej pracy, ale darem, jako że to „Duch Święty rozlewa świętość wszędzie w świętym i wiernym ludzie Bożym”32. Kościół więc, który podąża za Panem i rozeznaje Jego wolę, jest prowadzony przez Ducha i uświęcany przez Niego.

$\mathrm{Na}$ koniec warto wspomnieć o tym, o czym modlitwa nie mówi. Nie mówi ona nic o relacji Kościoła ze światem ${ }^{33}$. Cała treść oracji przesiąknięta jest tą jedną troską, aby podobać się Bogu, aby poznawać Jego wolę, za nią podążać i stawać się jej świadkami. Owa fundamentalna dla Kościoła relacja z Bogiem, wokół której skupia się teologia modlitw na zgromadzenie synodalne, jest źródłem tożsamości ludu Bożego. Tylko wówczas, kiedy wspólnota jest przeniknięta tą troską i otwarta na przemieniającą moc Ducha Świętego, może stać się autentycznym świadkiem wobec świata, do którego nie idzie z duchem prozelityzmu, ale miłości ${ }^{34}$.

${ }^{30}$ Por. Franciszek, Evagngelii gaudium 30: „Zachęcam wszystkie Kościoły partykularne do wejścia w zdecydowany proces rozeznania, oczyszczenia i reformy”.

31 Tenże, Gaudete et exsultate, Częstochowa 2018, 9.

32 Tamże, 6.

33 Ten brak nie oznacza, że relacja Kościół-świat jest sprzeczna z ideą synodalności. Wręcz przeciwnie, „synodalność jest przeżywana w Kościele w służbie jego misji” (La sinodalità nella vita e nella missione della Chiesa, 53), a cały lud jest podmiotem ewangelizacji (por. Franciszek, Evangelii Gaudium, Częstochowa 2014, 110-134 (AAS 105 (2013) 1019-1137)). Brak odniesienia do świata wskazuje raczej na fakt, że modlitwa liturgiczna obejmuje fundamentalną relację Bóg-Kościół, wobec której relacja Kościoła do świata jest wtórna i której jest podporządkowana.

${ }^{34}$ Por. S. Jeziorski, "The Liturgy and the Church in the Contemporary World”, „Liturgia Sacra” 25 (2019) 450-451. 


\section{ZAKOŃCZENIE}

Jeśli liturgia jest miejscem, w którym synodalność Kościoła objawia się w sposób najpełniejszy, to treść takiej modlitwy powinna znajdować swoje odzwierciedlenie w stylu życia, który wspólnota celebrująca podejmuje. Przedstawione tutaj przewodnie myśli lex orandi mogą więc stać się inspiracją dla modus vivendi Kościoła odkrywającego swoją synodalną tożsamość. Kościół zwrócony ku Bogu, gotowy wędrować ku Niemu, inspirowany i ożywiany Jego Duchem, może stać się Ludem Bożym w drodze, której podjęcia Bóg dzisiaj od niego oczekuje.

\section{BIBLIOGRAFIA}

Augustyn, Homilie na Ewangelię i pierwszy list św. Jana, cz. 1, Warszawa 1977.

Caeremoniale Episcoporum, ex Decreto Sacrosancti Oecumenici Concilii Vaticani II instauratum, auctoritate Ioannis Pauli PP. II promulgatum, Editio Typica, Città del Vaticano 1995, 1169.

Cattaneo E., Il culto cristiano in Occidente. Note storiche, Roma 1983.

Commissione Teologica Internazionale, La sinodalità nella vita e nella missione della Chiesa, Città del Vaticano 2018.

Congar Y., Les voies de Dieu vivant. Théologie et vie spirituelle, Paris 1962.

de Fraine J., A. Vanhoye, „Serce”, w: Słownik teologii biblijnej, red. X. Léon-Dufour, Poznań 1994.

Dianich S., „Sinodalità”, w: Teologia, red. G. Barbaglio, G. Bof, S. Dianich, Cinisello Balsamo 2002, s. 1522-1531.

Ellebracht M.P., Remarks on the vocabulary of the ancient orations in the Missale Romanum, Utrecht 1963.

Franciszek, „Synodalnośc” konstytutywnym wymiarem Kościoła, „L'Osservatore Romano”. Wydanie polskie 11 (377) 2015, 5; (AAS 107 (2015), 1139).

Franciszek, Evangelii Gaudium, Częstochowa 2014, 110-134; (AAS 105 (2013) 1019-1137).

Jeziorski S., The Liturgy and the Church in the Contemporary World, „Liturgia Sacra” 25 (2019), s. 441-454.

Lampe G., A Patristic Greek Lexicon, Oxford 1968.

Le sacramentaire Grégorien. Ses principales formes d'après les plus anciens manuscrits, ed. J. Deshusses, vol. 1, Éd. Universitaires Fribourg Suisse, Fribourg Suisse 1979.

Missale Romanum ex decreto Sacrosancti Oecumenici Concilii Vaticani II instauratum auctoritate Pauli PP. VI promulgatum, Ioannis Pauli PP. II cura recognitum, Editio typica tertia, LEV, Città del Vaticano 2008) 
Missale Romanum ex decreto SS. Concilii Tridentini restitutum Summorum Pontificium cura recognitum, Editio typica 1962, red. M. Sodi, A. Toniolo, Città del Vaticano 2007.

Ogólne Wprowadzenie do Mszału Rzymskiego, Poznań 2006.

Sacramentarium Fuldense saeculi X. Cod. Theol. 231 der K. Universitätsbibliothek zu Göttingen. Text und Bilderkreis (43 Tafeln). Als Festgabe des Historischen Vereins der Diözese Fulda zum 50 Jährigen Priesterjubiläum Sr. Eminenz des Hochwürdigsten Herrn Fürstbischofs von Breslau, Georg Kardinal Kopp, ehemaligen Bischofs von Fulda (1881-1887), red. G. Richter, A. Schönfelder, Fulda 1912, (HBS 101), Henry Bradshaw Society, London 1977.

Słownik łacińsko-polski, red. M. Plezia, t. I: A-C, Warszawa 1998.

Słownik łacińsko-polski, red. M. Plezia, t. III: I-O, Warszawa 1998.

Sobór Watykański II, Konstytucje, dekrety, deklaracje. Tekst łacińsko-polski, Poznań 2008. Vogel C., Medieval Liturgy: An Introduction to the Sources, Washington 1986.

Zurek P., Indagine sulla sinodalità: la riflessione cattolica dopo il Concilio Vaticano II con alcuni risvolti ecumenici, Roma 2002. 